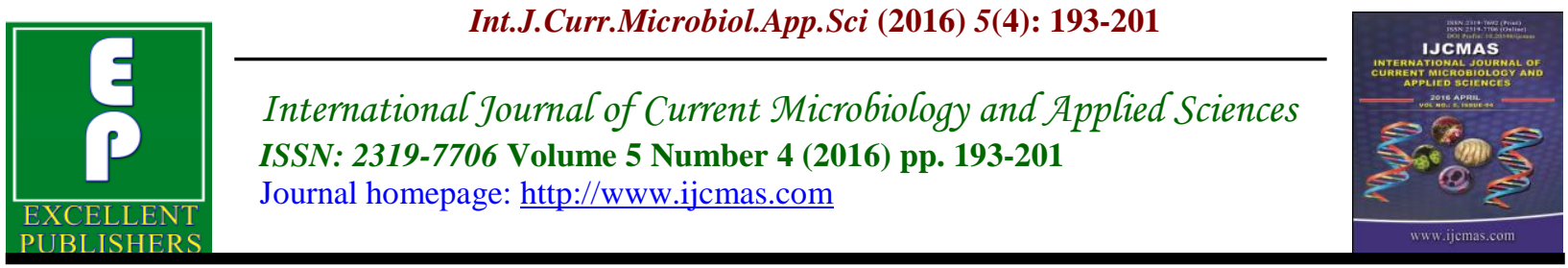

Original Research Article

http://dx.doi.org/10.20546/ijcmas.2016.504.024

\title{
Antiulcer Activity of Morinda citrifolia Linn. Root Extracts
}

\author{
Vijay Dnyandeo Tambe ${ }^{1 *}$ and Rajendra Sudhakar Bhambar ${ }^{2}$ \\ ${ }^{1}$ Department of Pharmacognosy, Pravara Rural College of Pharmacy, A/P-Loni, \\ Tal-Rahata, Dist-Ahmednagar-413 736 Maharashtra, India \\ ${ }^{2}$ Department of Pharmacognosy, MGV'S College of Pharmacy, Panchvati, Nasik, \\ Maharashtra, India \\ *Corresponding author
}

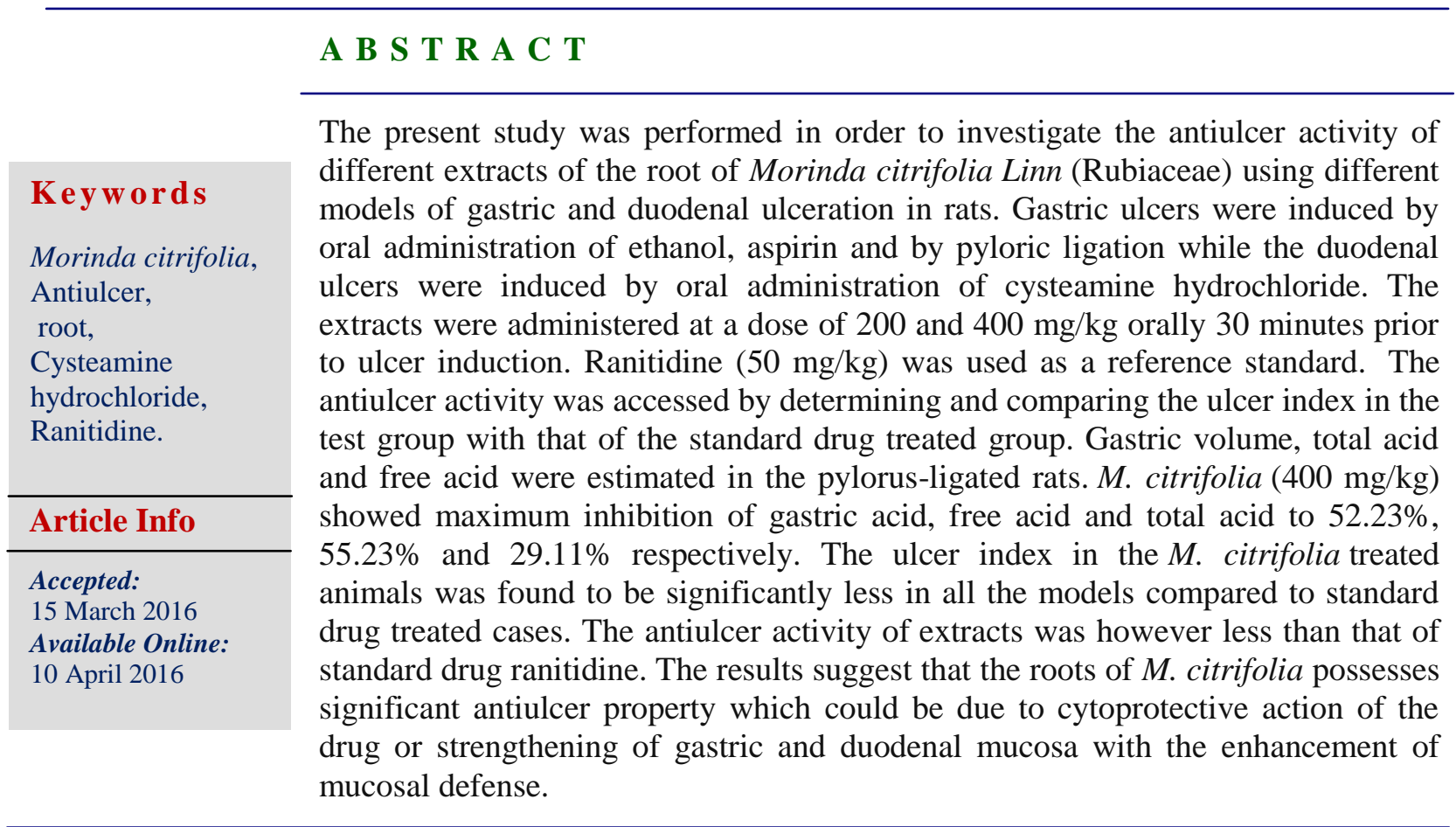

\section{Introduction}

Nature has provided a complete storehouse of remedies to cure ailments of mankind (Gangadhar et al., 2012; Rahman et al., 2011). There is a widespread belief that green medicines are healthier, though the recovery of disease by plant medicine is slow, the therapeutic use of medicinal plant is becoming popular because of its inability to cause side effects and effective for antibiotic resistant microorganisms (Perumalsamy et al., 2008). India is well known for its rich traditional system of medicine, besides a vast reservoir of living traditions of ethno medicine.

Morinda citrifolia Linn. Family Rubiaceae known commercially as "Noni" grows widely throughout the Pacific and is one of the most significant sources of traditional 
medicines among Pacific island societies. The plant is a bush to small tree growing from 2 to 6 meters tall. Distinctive varieties exist with differing leaf morphology. Leaves may be rounded, elliptic, or long and straplike. Larger rounded leaves are 15 to $30 \mathrm{~cm}$ wide by 20 to $40 \mathrm{~cm}$ long. Strap-like leaves may be as narrow as $10 \mathrm{~cm}$, and as long as $60 \mathrm{~cm}$. The globular compound fruits vary in size from 3 to $10 \mathrm{~cm}$ wide and are sometimes over $20 \mathrm{~cm}$ long. Fruits are green until maturity, when they rapidly change to a light yellow, then light yellow and translucent white. Fruit scent varies, with some varieties being virtually odorless, but more common, vigorous growing varieties having a strong smell of butyric acid when ripe. The roots and inner bark may have little coloration or may range from bright yellow to red. The Noni plant is used in combinations for herbal remedies. The fruit juice is in high demand in medicine for different kinds of illnesses such as arthritis, diabetes, high blood pressure, muscle aches and pains, gastric ulcers, menstrual difficulties, headaches, heart disease, AIDS, cancers, gastric ulcers, sprains, mental depression, senility, poor digestion, atherosclerosis, blood vessel problem, and drug addiction (Wang et al., 2002).

Traditionally peptic ulcers have been described as an imbalance between the luminal acid peptic attack versus the mucosal defense (Mutra et al., 1996). The treatment of peptic ulcers with plant products used in folk medicine and the protection of induced gastric ulcer in laboratory animals using medicinal plants were reported (Disi et al., 1998). Generally plant flavonoids have been found to be effective against ulcer in experimental animals (Lewis et al., 1999) and exhibit several biological effects (Rajnarayana et al., 2001). A number of major components has been identified in the Noni plant such as octoanoic acid, potassium, vitamin c, scopoletin, terpenoids, alkaloids, anthraquinones (such as nordamnacanthal, morindone, rubiadin, rubiadia-1-methyl ether, antraquinone glycosides) $\beta$-sitosterol, carotene, vitamin A, flavone glycosides, linoleic acid, alizarin, amino acids, acubin, 1asperuloside, caproic acid, caprylic acid, ursolic acid, rutin and putative proxeronine (Rastogi and Mehrotra, 1990). Antitumor activity expressed in enhanced survival of tumor-bearing mice has been demonstrated after treating with juice extracts (Hirazumi et al., 1994; 1999). Aqueous extracts of roots were shown to have an analgesic effect on mice without any sign of toxicity and a sedative effect at high doses (Youonos et al., 1990). The plant is said to possess antipyretic, antidiabetic and anticancer activity (Maurya and Srivastava, 2011).

Peptic ulcer disease deaths in India reached $1.2 \%$ of total deaths. The age adjusted Death Rate is 12.37 per 100,000 of population ranks India is 5 in the world. Peptic ulcer is an excoriated area of the gastric or duodenal mucosa is a chronic and recurrent disease (Guyton and Hall, 2000). It is generally recognized that peptic ulcer is caused by a lack of equilibrium between the gastric aggressive factors and the mucosal defensive factors (Muralidharan and Srikanth, 2009). The predominant causes of peptic ulcer are infection with the bacterium called Helicobacter pylori (H. pylori) and the use of Non Steroidal Anti-Inflammatory Drugs (NSAIDs) such as aspirin and ibuprofen (Goroll and Mulley, 2009).

The plant Morinda citrifolia has been claimed to have antiulcer activity (Wang et al., 2002), but no detailed scientific investigations have been carried out to define the antiulcer activities of Morinda citrifolia root. Thus the present investigation was carried out to study the antiulcer 
activity of Morinda citrifolia root extracts. The effect produced by Morinda citrifolia was compared with a standard drug as ranitidine.

\section{Materials and Methods}

\section{Collection and Authentication of Plant Material}

Morinda citrifolia roots were collected from Mahatma Phule Krishi Vidyapeeth, Rahuri, District Ahemednagar, Maharashtra. The plant was identified and authenticated by Dr. S. K. Salunkhe, Head Department of Botany, PVP College Pravaranagar, India. A voucher specimen was deposited in the laboratory for future reference.

\section{Preparation of Extract}

The roots collected were washed with running tap water and made into pieces. They were oven-dried at $45^{\circ} \mathrm{C}$ for 2 days and made into a powder. The ground powder was extracted with methanol in a water bath at room temperature for $24 \mathrm{hr}$. The solvent was then removed by filtration and fresh solvent was then added to the plant material. The extraction process was twice repeated.

The combined filtrates were then evaporated under reduced pressure to give a viscous mass. This methanol crude extract was further extracted with ethyl acetate and water. Then the fractions were separated using separating funnel. These ethyl acetatesoluble fractions were later evaporated to obtain the ethyl acetate extract (Zin et al., 2002). The extract was stored at $0-4^{\circ} \mathrm{C}$. The percentage yield was found as $18 \%$. This extract was used for experimental studies in animal models.

\section{Experimental Animals}

Inbred colony strains of Wistar rats of either sex weighing 200-250 gms were used for the experiments. The animals were maintained in polypropylene cages of standard dimensions at a temperature of $28 \pm 1^{\circ} \mathrm{C}$ and standard 12 hour: 12 hour day/night cycle. The animals were fed with standard rodent pellet diet (Hindustan Lever Ltd.) and water ad libitum. Prior to the experiment, the animals were acclimatized to the laboratory conditions. The experimental protocol was approved by Institutional Animal Ethical Committee (IAEC) constituted under CPCSEA in the college.

\section{Preliminary Phytochemical Studies}

The ethyl acetate extract of the roots of Morinda citrifolia Linn was subjected to preliminary phytochemical screening (Harborne, 1984).

\section{Acute Toxicity Studies}

Albino mice weighing 22-25 g selected by random sampling technique were used in the study. Acute oral toxicity was performed as per OECD- 423 guidelines (Ecobichon, 1997). The animals were fasted overnight, provided only water after which extract was administered to the groups orally at the dose level of $5 \mathrm{mg} / \mathrm{kg}$ body weight by gastric intubation and the groups were observed for 14 days.

If mortality was observed in 2 or 3 animals among 6 animals then the dose administered was assigned as a toxic dose. If mortality was observed in one animal, then the same dose was repeated again to confirm the toxic dose. If mortality was not observed, the procedure was repeated for further higher doses such as 50, 300 and $2000 \mathrm{mg} / \mathrm{kg}$ body weight. The animals were observed for toxic symptoms such as behavioral changes, locomotion, convulsions and mortality for 72 hours. 


\section{Aspirin-induced Gastric Lesions}

Aspirin (0.2 gm/kg $\mathrm{x} \quad 3$ days) were administered once per day to groups of animals for the number of days specified (Goel et al., 1986). Animals of control group received $1 \%$ carboxy methyl cellulose (CMC) suspension and test groups received M. citrifolia root extract suspension orally at two dose levels (200 and $400 \mathrm{mg} / \mathrm{kg}$ ) for 10 days. From day 8 the animals received $\mathrm{CMCl}$ M. citrifolia two hours prior to the administration of aspirin. Overnight fasted animals were sacrificed by cervical dislocation one hour after the last dose of ulcerogen. The stomach was incised along the greater curvature and examined for ulcers.

\section{Alcohol-induced Gastric Lesions}

The rats fasted for $24 \mathrm{~h}$ before the experiment (Abdulla et al., 2010), but were allowed free access to drinking water up till $2 \mathrm{~h}$ before the experiment. Groups of rats fasted received either $M$. citrifolia root extracts (200 and $400 \mathrm{mg} / \mathrm{kg}$ ) or control vehicle Ulcer control groups were orally administered vehicle (10\% Tween 20, 5 $\mathrm{ml} / \mathrm{kg}$ ). The reference group received oral doses of $50 \mathrm{mg} / \mathrm{kg}$ Ranitidine in $10 \%$ Tween 20 as positive control. After $30 \mathrm{~min}$, ulcer was induced by oral administration of $80 \%$ ethanol $(5 \mathrm{ml} / \mathrm{kg})$. The animals were euthanized 60 min later under an overdose of xylazin and ketamine anesthesia and sacrificed. The stomach was removed, opened along the greater curvature and sum of length of lesions (mm) was calculated and expressed as lesion index.

\section{Pylorus Ligated Rats}

M. citrifolia root extracts (200 and 400 $\mathrm{mg} / \mathrm{kg}$ ) was administered for a period of 7 days. On day 7, after the last dose of $M$. citrifolia, the rats were kept for 24 hours fasting and care was taken to avoid coprophagy. Under light ether anesthesia, the abdomen was opened and pylorus was ligated without causing any damage to its blood vessels. The stomach was replaced carefully and the abdominal wall was closed with interrupted sutures. The animals were deprived of water during the postoperative period (Shay et al., 1945). Four hours after ligation, stomachs were dissected out and contents were collected into clean tubes. Volume, $\mathrm{pH}$, free acid and total acid content of gastric juice were determined. The contents were centrifuged, filtered and subjected to titration for estimation of free and total acidity. $1 \mathrm{ml}$ of centrifuged and filtered gastric secretion was titrated against $0.1 \mathrm{~N}$ Sodium hydroxide using Topfers reagent as indicator for determination of free acidity and $1 \%$ phenolphthalein as indicator for combined acidity. The sum of the two titrations was total acidity (Parmar et al., 1984). The stomach was opened along the greater curvature and examined for ulcers. The ulcer index was evaluated using the method described earlier (Souza-Formigoni et al., 1991).

\section{Cysteamine $\mathrm{HCl}$ Induced Duodenal Ulcers}

Rats were treated with extract of $M$. citrifolia (200 \& $400 \mathrm{mg} / \mathrm{kg}$ ) orally for a period of 7 days. On day 8, the overnight fasted animals were given a single subcutaneous injection of cysteamine hydrochloride $(30 \mathrm{mg} / \mathrm{kg})$ and the animals were killed by cervical dislocation after 18 hours (Borella et al., 1979) duodenum was examined for the presence or absence of ulcers.

\footnotetext{
Difference in control group reading $(\mathrm{C})$ and test drug reading $(\mathrm{T})$

$\%$ Inhibition $=$ - $----------------\times 100$
Control group reading $(\mathrm{C})$
} 


\section{Statistical Analysis}

Statistical analysis was carried out by using ANOVA followed by Dunnet's multiple comparison tests using Graph pad PRISM software version 4.03 (2005). ' $P$ ' values $<0.05$ were considered significant.

\section{Results and Discussion}

The preliminary phytochemical screening carried out on ethyl acetate extract of $M$. citrifolia roots revealed the presence of phytoconstituents such as carbohydrates, proteins, alkaloids, glycosides, phenols, flavanoids, sterols, gums and mucilage (Table 1).

The extract did not produce any toxic symptoms of mortality up to the dose level of $2000 \mathrm{mg} / \mathrm{kg}$ body weight in rats, hence the drugs were considered safe for further pharmacological screening. According to the OECD-423 guidelines for acute oral toxicity, the LD50 dose of $2000 \mathrm{mg} / \mathrm{kg}$ and above is categorized as unclassified.

During the course of the study, the incidence and severity of aspirin and alcohol induced ulcerations were significantly reduced by $M$. citrifolia. Induction of duodenal ulcers in rats with cysteamine hydrochloride showed the presence of ulcers in all the animals in the control group, which was significantly reduced in the $M$. citrifolia treated group. The values are shown in Table 2.

Effect of M. citrifolia on gastric volume, free acid, total acid and ulcer in pylorus ligated rats were studied. M. citrifolia extracts ( 200 and $400 \mathrm{mg} / \mathrm{kg}$ ) inhibited the volume of gastric juice secreted by the control rats by $22.44 \%$ and $52.23 \%$, respectively. The free acid and the total acid were reduced by the extract to 37.38 ,
$17.13 \%$ and $55.23,29.11 \%$, respectively for the 200 and $400 \mathrm{mg} / \mathrm{kg}$. M. citrifolia root extracts administered in doses 200 and 400 $\mathrm{mg} / \mathrm{kg}$ orally, caused a dose dependent decrease in ulcer index in pylorus ligated rats. The values are shown in Table 3 .

In most of the cases the etiology of the ulcer is unknown. It is generally accepted that it results from an imbalance between aggressive factors and the maintenance of the mucosal integrity through the endogenous defense mechanism (Piper and Stiel, 1986). To regain the balance, different therapeutic agents including plant extracts are used to inhibit the gastric acid secretion or to encourage the mucosal defense mechanisms by increasing mucus production, stabilizing the surface epithelial cells, or interfering with the prostaglandin synthesis.

Even though many products in the market for the treatment of gastric ulcers, including antacids, proton pump inhibitors, anticholinergics and histamine $\mathrm{H} 2-$ antagonists, are used, most of these drugs produce several adverse reactions, such as gynecomastia, hematopoietic changes, acute interstitial nephritis (Ra and Tobe, 2004), thrombocytopenia (Zlabek and Anderson, 2002), anaphylaxis reactions (Gonzalez et al., 2002), nephrotoxicity and hepatotoxicity (Fisher and Le Couteur, 2001). Medicinal plants are amongst the most attractive sources of new drugs and have been shown to give promising results in treatment of gastric and duodenal ulcers. The anti ulcerogenic activity of $M$. citrifolia was evaluated by employing aspirin and alcohol induced ulcerations in rats. Non-steroidal anti-inflammatory drugs (NSAIDs) like aspirin are known to induce gastric ulceration. 
Table.1 Preliminary Phytochemical Study of M. citrifolia Root Ethyl Acetate Extract

\begin{tabular}{|c|c|c|}
\hline $\begin{array}{c}\text { Sr. } \\
\text { No. }\end{array}$ & Tests & Results \\
\hline 1. & Test for Carbohydrates & ++ \\
\hline 2. & Test for Alkaloids & ++ \\
\hline 3. & Test for Gums and mucilage & ++ \\
\hline 4. & Test for Steroids & -- \\
\hline 5. & Test for Sterols & -- \\
\hline 6. & Test for Glycosides & ++ \\
\hline 7. & Test for Flavanoids & ++ \\
\hline 8. & Test for Proteins & ++ \\
\hline 9. & Test for Phenols & ++ \\
\hline 10. & Test for Saponins & -- \\
\hline 11. & Test for Terpenes & -- \\
\hline
\end{tabular}

++ indicates the presence of compounds

-- indicates absence of compounds

Table.2 Anti Ulcer Activity of Ethyl Acetate Extract of Morinda citrifolia Root

\begin{tabular}{|c|c|c|c|c|}
\hline \multirow{2}{*}{$\begin{array}{c}\text { Ulcerogen Used } \\
(\text { Dose })\end{array}$} & Control & \begin{tabular}{c} 
M. citrifolia Ulceot Index \\
extract \\
\cline { 2 - 5 }
\end{tabular} & $\begin{array}{c}\text { M. citrifolia root } \\
\text { extract } \\
(\mathbf{4 0 0 m g} / \mathbf{m g})\end{array}$ & $\begin{array}{c}\text { Ranitidine } \\
\mathbf{( 5 0 m g} / \mathbf{k g})\end{array}$ \\
\hline $\begin{array}{c}\text { Aspirin } \\
(200 \mathrm{mg} / \mathrm{kg})\end{array}$ & $26.12 \pm 0.39$ & $19.06 \pm 0.72^{*}$ & $14.40 \pm 0.36^{*}$ & $9.42 \pm 0.17^{*}$ \\
\hline $\begin{array}{c}\text { Alcohol }(80 \%) \\
(5 \mathrm{ml} / \mathrm{kg})\end{array}$ & $37.02 \pm 0.36$ & $24.90 \pm 0.36^{*}$ & $22.00 \pm 0.30^{*}$ & $17.00 \pm 0.14^{*}$ \\
\hline $\begin{array}{c}\text { Cysteamine HCl } \\
(30 \mathrm{mg} / \mathrm{kg})\end{array}$ & $33.70 \pm 0.38$ & $21.14 \pm 0.27^{*}$ & $16.00 \pm 0.32^{*}$ & $13.82 \pm 0.30^{*}$ \\
\hline
\end{tabular}

Values are mean \pm SEM of 6 animals in each group $(n=6) ; * P<0.05$ compared with respective control group

Table.3 Effect of Morinda citrifolia Root Ethyl Acetate Extract on Gastric Volume, Free Acid, Total Acid and Ulcer Index in Pylorus Ligated Rats

\begin{tabular}{|c|c|c|c|c|c|}
\hline \multirow{2}{*}{ Parameters } & \multicolumn{5}{|c|}{ Groups } \\
\cline { 2 - 6 } & Control & $\begin{array}{c}\text { M. citrifolia } \\
\text { root extract } \\
(\mathbf{2 0 0} \mathbf{~ m g / k g})\end{array}$ & $\begin{array}{c}\text { Percentage } \\
\text { inhibition }\end{array}$ & $\begin{array}{c}\text { M. citrifolia } \\
\text { root extract } \\
\mathbf{( 4 0 0 ~ m g / k g )}\end{array}$ & $\begin{array}{c}\text { Percentage } \\
\text { inhibition }\end{array}$ \\
\hline $\begin{array}{c}\text { Gastric volume } \\
(\mathrm{ml} / 100 \mathrm{~g})\end{array}$ & $7.62 \pm 0.65$ & $5.91 \pm 0.42^{*}$ & 22.44 & $3.64 \pm 0.15$ & 52.23 \\
\hline $\begin{array}{c}\text { Free acid } \\
(\mu \mathrm{Eq} / 100 \mathrm{~g} / 4 \mathrm{~h})\end{array}$ & $401.00 \pm 0.98$ & $251.10 \pm 1.08^{*}$ & 37.38 & $179.50 \pm 1.53^{*}$ & 55.23 \\
\hline $\begin{array}{c}\text { Total acid } \\
(\mu \mathrm{Eq} / 100 \mathrm{~g} / 4 \mathrm{~h})\end{array}$ & $495.17 \pm 2.74$ & $410.30 \pm 2.23^{*}$ & 17.13 & $351.00 \pm 2.84^{*}$ & 29.11 \\
\hline Ulcer Index & $28.22 \pm 0.64$ & $23.91 \pm 0.49^{*}$ & 15.27 & $18.16 \pm 0.87^{*}$ & 35.64 \\
\hline
\end{tabular}

Values are mean \pm SEM of 6 animals in each group $(n=6) ; * P<0.05$ compared with respective control group 


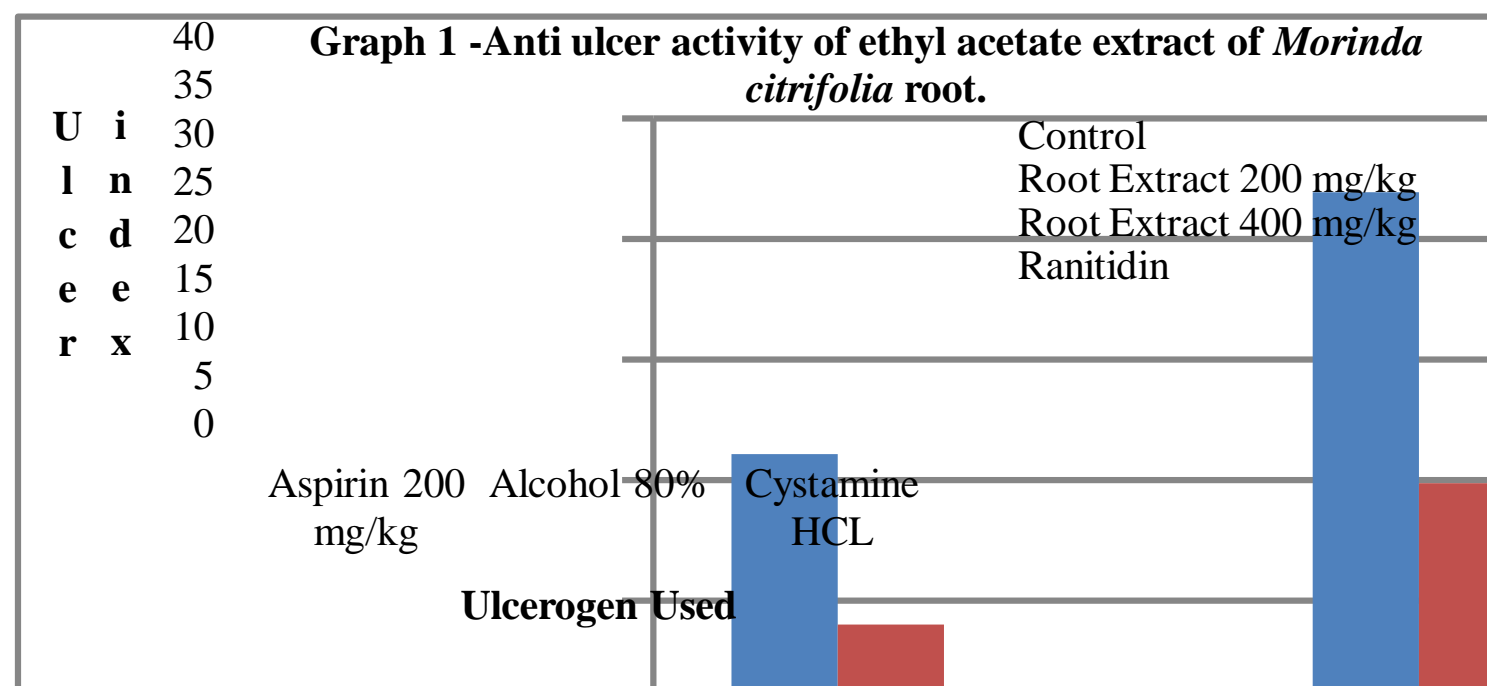

The reason being attributed principally to inhibition of biosynthesis of 'cytoprotective prostaglandins' (by inhibition of cyclooxygenase pathway of arachidonic acid metabolism), resulting in overproduction of leukotrienes and other products of 5lipoxygenase pathway (Rainsford, 1987). Hence, the protective action of $M$. citrifolia root against aspirin- induced gastric lesions could possibly be due to its 5-lipoxygenase inhibitory effect.

Ethanol-induced gastric lesion formation may be due to stasis in gastric blood flow, which contributes to the development of the haemorrhage and necrotic aspects of tissue injury (Guth et al., 1984). It has also been reported that leukotrienes antagonist and 5lipoxygenase inhibitors are capable of inhibiting alcohol and NSAIDs-induced gastric ulceration in rats (Parnham and Brune, 1987). Therefore the protection afforded by the $M$. citrifolia root extracts against alcohol and aspirin-induced gastric ulceration could also be due to inhibition of 5-lipoxygenase pathway or to leukotriene's antagonistic activity. As the defense potential of mucus perimeter of gastric mucosa depends upon a delicate balance between the processes affecting the synthesis and secretion of its mucin constituents. The effect of $M$. citrifolia on gastric volume, free acid and total acid was evaluated in pyloric-ligated rats. $M$. citrifolia prevented the mucosal lesions induced by aspirin/alcohol. The primary therapeutic approach of an antiulcer agent involves maintenance of a delicate balance of factors controlling the synthesis, secretion and breakdown of its proteins, glycoproteins, and lipid components, so as to strengthen the mucosal integrity (Brown, 1978).

In the present study $M$. citrifolia root showed prevention of gastric lesions in the experimental models. $M$. citrifolia was found to increase the mucous and decrease the acid volume, free and total acid contents in rats. $M$. citrifolia treatment affects the parameters that influence the initiation and perpetuation of ulceration. In addition, there is extensive experimental evidence, which indicates that certain substances through free radical scavenging protect the gastric mucosa (Glavin and Szabo, 1992).

\section{Acknowledgment}

The authors are thankful to Principal Dr. R. S. Bhambar, MGV'S collge of pharmacy Panchavati, Nasik (MS) for granting 
permission to carry out the research work.

\section{References}

Abdulla, M.A., Ahmed, K.A.A., AL-Bayaty, F.H., Masood, Y. 2010. Gastroprotective effect of Phyllanthus niruri leaf extract against ethanol-induced gastric mucosal injury in rats. Afr. J. Pharm. Pharmacol., 4(5): 226-230.

Borella, E., Seethaler, K., Lipmann, W. 1979. Sucralfate: antipeptic, antiulcer activities and antagonism of gastric emptying. Arzneimittelforschung, 29(5): 793-798.

Brown, G.G. 1978. An introduction to Histotechnology, 1: 293-308.

Disi, Ahmad, M., Tamimi, Salah, O., Abuereish Ghaleb, M. 1998. Effects of Anchusa strigosa root aqueous extract on gastric ethanol-induced ulcer in laboratory animals. J. Ethnopharmacol., 60(3): 189198.

Ecobichon, D.J. 1997. The Basis of Toxicity Testing, CRC Press, New York, 3: 43-86.

Fisher, A., Le Couteur, D.G. 2001. Nephrotoxicity and hepatotoxicity of histamine H2 receptor antagonists. Drug Safety, 24(1): 39-57.

Galvin, G.B., Szabo, S. 1992. Experimental gastric mucosal injury, laboratory models reveal mechanism of pathogenesis and new therapeutic strategies. FASEB J., 6: 821-825.

Gangadhar, M., Shraddha, K., Ganesh, M. 2012. Antimicrobial screening of garlic (Allium sativum) extracts and their effect on glucoamylase activityin-vitro. J. Appl. Pharm. Sci., 2(01): 106-108.

Goel, R.K., Gupta, S., Shankar, R., Sanyal, A.K. 1986. Anti-ulcerogenic effect of banana powder (Musa sapientum var. paradisiaca) and its effect on mucosal resistance. J. Ethnopharmacol., 18(1): 3334.

Gonzalez, P., Soriano, V., Lopez, P., Niveiro, E. 2002. Anaphylaxis to proton pump inhibitors. Allergie Immunopathol., 30(6): 342-343.
Goroll, A.H., Mulley, A.G. 2009. Primary Care Medicine. Philadelphia, 6: 537- 548.

Guth, P.H., Paulsen, G., Nagata, H. 1984. Histologic and microcirculatory changes in alcohol-induced gastric lesions in the rat: effect of prostaglandin cytoprotection. Gastroenterol., 87(5): 1083-1090.

Guyton, A.C., Hall, J.E. 2000. Textbook of medical physiology [M]. 10th Ed. Philadelphia: Saunders: 397-398.

Harborne, J.B. 1984. Phytochemical methods, 2: 50 .

Hirazumi, A., Feurasawa, E. 1999. An immunomodulatory polysaccharide-rich substance from the fruit juice of Morinda citrifolia (noni) with antitumour activity. Phytother. Res., 13(5): 380-387.

Hirazumi, A., Furrasawa, E., Chou, S.C., Hokama, Y. 1994. Anticancer activity of Morinda citrifolia (noni) on intraperitoneally implanted Lewis lung carcinoma in syngeneic mice. Proc. West Pharmacol. Soc., 37: 145-146.

Lewis, David, A., Fields, William, N., Shaw, Graham P. 1999. A natural flavonoid present in unripe plantain banana pulp (Musa sapientum L. var. paradisiaca) protects the gastric mucosa from aspirininduced erosions. J. Ethnopharmacol, 65(3): 283-288.

Mohd Zin, Z., Abdul-Hamid, A., Osman, A. 2002. Anti oxidative activity of extracts from Mengkudu (Morinda citrifolia L.) root, fruit and leaf. Food Chem., 78(2): 227-231.

Muralidharan, P., Srikanth, J. 2009. Antiulcer activity of Morinda citrifolia Linn fruit extracts. J. Sci. Res., 1(2): 345-352.

Mutra, S.K., Gopumadhavan, S., Hemavathi, T.S., Muralidhar, T.S., Venkataranganna, M.V. 1996. Protective effect of UL-409, a herbal formulation against physical and chemical factor induced gastric and duodenal ulcers in experimental animals. J. Ethnopharmacol., 52(3): 165-169.

Parmar, N.S., Hennings, G., Gulati, O.P. 1984. The gastric antisecretory activity of 3methoxy-5,7,3'4'-tetrahydroxyflavan (ME)--a specific histidine decarboxylase 
inhibitor in rats. Agents Actions, 15(3-4): 143-145.

Parnham, M.J., Brune, K. 1987. Meeting report: Therapeutic control of inflammatory diseases. Agents and Actions, 21(3): 232-234.

Perumalsamy, R., Ignacimuthu, S., Sem, A. 2008. Screening of 34 Indian medicinal plants for antibacterial properties. $J$. Ethnopharmacol., 62: 173-182.

Piper, D.W., Stiel, D.D. 1986. Pathogenesis of chronic peptic ulcer, current thinking and clinical implications. Med. Prog., 2: 7-10.

Ra, A., Tobe, S.W. 2004. Acute Interstitial Nephritis Due to Pantoprazole. Ann. Pharmacother., 38: 41-45.

Rahman, M.S., Salehin, M.F., Jamal, M., Parvin, A., Alam, M.K. 2011. Antibacterial activity of Argemone mexicana L. against water borne microbes. Res. J. Med. Pl., 5(5): 621-626.

Rainsford, K.D. 1987. The effects of 5lipoxygenase inhibitors and leukotriene antagonists on the development of gastric lesions induced by nonsteroidal antiinflammatory drugs in mice. Agents and Actions, 21(3-4): 316-319.

Rajnarayana, K., Reddy, M. Sripal, Chaluvadi, M.R., Krishna, D.R. 2001. Bioflavonoids classification, pharmacological, biochemical effects and therapeutic potential. Indian J. Pharmacol., 33: 2-16.
Rastogi, P., Mehrotra, B.N. 1990. Compendium of Indian Med. Pl., 1: 279.

Robert, A., Nezamis, J.E., Lancaster, C., Hanchar, A.J. 1979. Cytoprotection by prostaglandins in rats. Prevention of gastric necrosis produced by alcohol, $\mathrm{HCl}$, $\mathrm{NaOH}$, hypertonic $\mathrm{NaCl}$ and thermal injury. Gastroenterol., 77(3): 433-443.

Souza-Formigoni, M.L.O., Oliveira, M.O.M., Monteiro, M.U., Sileira-Filho, N.O., Braz, S., Carlini, E.A. 1991. Antiulcerogenic effects of two Maytenus species in laboratory animals. J. Ethnopharmacol., 34(1): 21-27.

Umashanker Maurya, Srivastava Shruti. 2011. Traditional Indian herbal medicine used as antipyretic, antiulcer, anti-diabetic and anticancer: a review. Int. J. Res. Pharm. Chem., 1(4): 1152-1159.

Wang, M.Y., West, B.J., Jensen, C.J., Nowicki, D., Su, C.X., Palu, A.K., Anderson, G. 2002. Morinda citrifolia (Noni): a literature review and recent advances in Noni research. Acta pharmcologica sinica, 23(12): 1127-1141.

Youonos, C., Rolland, A., Fluerentin, J., Lanhers, M., Missilin, R., Mortier, F. 1990. Analgesic and behavioural effects of Morinda citrifolia. Planta Medica, 56(5): 430-436.

Zlabek, J.A., Anderson, C.G. 2002. Lansoprazole-induced thrombocytopenia. Ann. Pharmacother., 36(5): 809-811.

\section{How to cite this article:}

Vijay Dnyandeo Tambe and Rajendra Sudhakar Bhambar. 2016. Antiulcer Activity of Morinda citrifolia Linn. Root Extracts. Int.J.Curr.Microbiol.App.Sci.5(4): 193-201. doi: http://dx.doi.org/10.20546/ijcmas.2016.504.024 